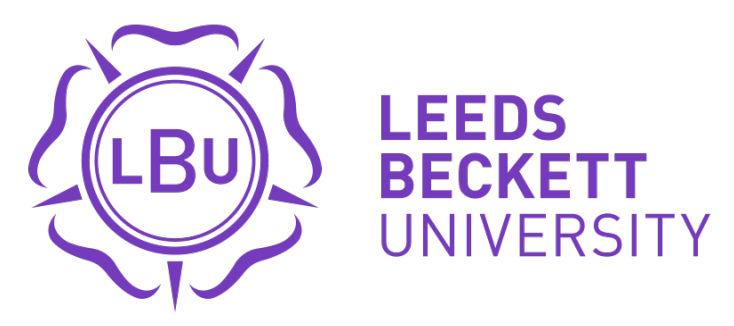

Citation:

Lamond, I (2019) Disruptive and adaptive methods in activist tourism studies: Sociospatial imaginaries of dissent. Tourism Geographies. ISSN 1461-6688 DOI: https://doi.org/10.1080/14616688.2019.1682653

Link to Leeds Beckett Repository record:

https://eprints.leedsbeckett.ac.uk/id/eprint/6202/

Document Version:

Article (Accepted Version)

This is an Accepted Manuscript of an article published by Taylor \& Francis in Tourism Geographies on 25 October 2019, available online: http://www.tandfonline.com/10.1080/14616688.2019.1682653

The aim of the Leeds Beckett Repository is to provide open access to our research, as required by funder policies and permitted by publishers and copyright law.

The Leeds Beckett repository holds a wide range of publications, each of which has been checked for copyright and the relevant embargo period has been applied by the Research Services team.

We operate on a standard take-down policy. If you are the author or publisher of an output and you would like it removed from the repository, please contact us and we will investigate on a case-by-case basis.

Each thesis in the repository has been cleared where necessary by the author for third party copyright. If you would like a thesis to be removed from the repository or believe there is an issue with copyright, please contact us on openaccess@leedsbeckett.ac.uk and we will investigate on a case-by-case basis. 


\section{Disruptive and adaptive methods in activist tourism studies: Socio-spatial imaginaries of dissent.}

Abstract

Around the world the twenty-first century has seen growth in the number and scale of protest events, mobilising substantial numbers of people to gather in acts of dissent. Central to understanding participation in such large-scale activist mobilities is an examination of those imaginaries of dissent, space and place associated with them. However, attempts to examine such imaginaries are hampered by traditional social science approaches that depoliticise participation and are often treated with suspicion by the protesters and those tasked with mitigating the impact of their activism. The disrUPt project confronted those issues by exploring disruptive and adaptive methods that could bring those imaginaries to the fore. The theoretical foundations of the project were rooted in those ideas in contemporary European thought around the philosophy of the event that conceptualise 'events' as sites of multiplicity and contestation (Badiou, 2017; Deleuze, 2014), articulated through the emerging field of critical event studies (Spracklen and Lamond, 2016) and the literature of activist tourism (Pezzullo, 2007). Four methodological approaches are explored, these are: the creation of a bicycle based mobile film projector, used to make visible spaces hidden by developments in the contemporary city; the presentation of augmented film screenings, which combine film presentation with non-traditional elements in non-traditional venues; activist film making with a group of female asylum seekers; and a series of conversations that brought together participants more commonly in opposition during events of dissent. The paper concludes that whilst the methods deployed were successful in facilitating the articulation of imaginaries of dissent, space and place, attached to protest and activist tourism, much more needs to be 
done to both draw such research approaches together and in the development of a deeper understanding of the use of disruptive and adaptive approaches to participatory data analysis.

Key words: protest; events of dissent; activist tourism; critical event studies; activist mobilities; socio-spatial imaginaries of dissent

\section{$\underline{\text { Introduction }}$}

The beginning of the twenty-first century has seen a significant growth in large scale, global, events of dissent. It is estimated that almost 11 million people in around 60 countries and more than 600 cities (Walgrave and Rucht, 2010) participated in demonstrations against going to war with Iraq on February 15th and 16th, 2003. In a period of just over three weeks, following the establishment of the Occupy encampment on Wall Street on the 17th September 2011, The Washington Post suggested there were camps in over 950 cities in 82 countries. On April 22nd, 2017 (World Earth Day), protesters in more than 500 cities around the world (Buncombe, 2017) declared that Donald Trump's position on climate change was a mistake that could have catastrophic, global, repercussions. Such large scale, time bound, mobilities, associated with activist events are a significant dimension in the geopolitical turn emerging in tourism geographies, symptomatic of what Mostafanezhad (2018) has referred to as "...the multi-scalar nature of geopolitics" (p345). Whilst ideas associated with activist tourism have been discussed since Dixon's (2001) consideration of activist mobilities in the formation of anti-globalisation movements, emergent from the World Trade Organization (WTO) protest in Seattle in 1999 (See, also, Bevington \& Dixon (2005)), activist tourism is a little explored area within event or tourism research. The first explicit discussion of the 
activist tourist appears in Phaedra Pezzullo's (2009) book Toxic Tourism, which addresses the layered and complex discourse of pollution and tourism from a perspective of travel to heavily polluted sites as a form of environmentalist advocacy. Significantly, for this paper, she also addresses the concept of the imaginary of space and place in relation to activist events and tourism, which I will consider shortly. More recently the debate has tended to focus on academic activism within Tourism Studies (For example: Hales et al, 2018; Ooi, 2019), and less so on the imaginary of space and place associated with activist events and mobilities.

Whilst there has been discussion around LGBT+ activism and travel, this has been quite limited. Reflection tends to be concerned with what Puar (2002) calls the "selling of liberation" (pp. 123), where the discourse of activism becomes negotiated as the original act of protest is colonised by globalised economic interests (Markwell and Waitt, 2009; Rojek, 2013). Others have drawn on the work of Urry (such as Urry, 1990 and 2001) to consider the gaze of the activist tourist in regions of conflict or space of tragedy (Brin, 2006; Hercbergs, 2012; Buda and Mcintosh, 2013). But the activist tourist, whose mobility is associated with embodied engagement in protest, does not fit this mould comfortably. Unlike most other forms of tourism, the activist tourist, carrying a placard or joining in a mass chant as they process through some of the primary transit routes of a city, may be more interested in being part of that upon which the gaze falls. They thus become both visitor and, providing the protest is successful in its disruption of daily routines and it is mediated well across multiple platforms, some form of attraction. Central then, to developing an understanding of the engaged activist tourist are the entwined imaginaries of space and place associated with participation in an event of dissent. I use the word 'imaginary' here in a sense derived 
from that of the social imaginary developed by Cornelius Castoriadis $(1999$, also Castoriadis and Ricoeur, 2017), to refer to those practices and discourses assumed to be associated with space and place as articulated by an individual or group engaged in visitor mobility. Grasping that complex and nuanced imaginary of the event of dissent becomes a truly critical project within tourism studies. For, as Bianchi (2009) argues, it endeavours to "...find ways of integrating the study of discourse with ongoing, as well as material forms of power (and, as such) ...constitutes a radical departure from the status quo in Tourism Studies". (p498)

The primary purpose of the "Creativity, protest and the city" project, otherwise known as disrUPt, was to draw together a small team of experienced researchers who could explore methodologies appropriate to studying the imaginary of dissent. It adopted a perspective that was closer to individual experience, rather than drawing generalised conclusions based on patterns discernible through the analysis of Big Data (Tsou, 2015). The project ran between October 2016 and October 2017, with most of the methods explored delivered across a number of cities in Yorkshire (England); primarily Leeds and Sheffield. The research team consisted of the author (as Principle Investigator) and four other academics (two from an events/tourism background, one from leisure studies, and two from cultural studies), and several external partners associated with activism in the region ${ }^{i}$. The external partners were self-selected following a general call for collaborators put out through connections already held by the research team. All the academics came from the same University, which was within the same geographical region as the research. 
A study of the imaginary of dissent can cut across multiple perspectives in critical research within tourism, leisure and event studies. However, given the proximity of that imaginary to the articulation of identity (Roberts, 2005) and construction of the 'other' (Glynos and Howarth, 2007) it can prove to be problematic when standard social science approaches are used to capture data. In order to address some of those concerns, DisrUPt set out to examine novel techniques that would engage with methods that were disruptive and adaptive. This was done to establish the viability of such approaches as tools for research, rather than as a means of capturing fresh data, or as a means of testing any existing theories or findings: that could be done in later research - if the methods tried were found to be of value.

The topic of this paper will be discussed over four steps. First, it will consider some of the limitations that are associated with the adoption of traditional social science methods when it comes to researching the imaginary of dissent. Following an outline of what CES is, I will argue that it can offer a pathway which can provide fresh opportunities for furthering research in the study of events of protest, activism and activist tourism. Second, after a brief description of the background to adaptive and disruptive methodologies, I will address the issue of what is to be understood by those terms within this paper. Third, the actual methods deployed by the disrUPt project will be described and, where appropriate, how they changed over the course of the project. The were four methods trialled. First, the creation of the kino-cine-bomber as a form of artefact based urban intervention. Second, the use of augmented film screenings as a disruptive visual method. Third, film making workshops as a means of articulating empowerment. Finally, the production of safe and structured environments, where participants, usually in a confrontational relationship 
during periods of protest, were able to meet and share their individual imaginaries of dissent through conversation. Finally, each of the methods described will be reviewed to examine the opportunities and limitations they exhibited, as well as any other issues that emerged which may impact their future viability as adaptive/disruptive methods.

\section{$\underline{\text { Researching the imaginary of dissent }}$}

An encounter with urban events of dissent, either as participant, spectator, or someone whose daily routine becomes disrupted, presents us with a complex and entwined set of imaginaries of space, place and time (Pavoni, 2018). The mainstays of social science research, such as the interview, focus group and survey, may offer a hint of the complexity at work within this diverse social ecosystem, but they tend to be traces, at best. Such fragments, symptoms of the 'event', require sensitive judgments around interpretation and the location of the researcher and the participant within the research process (Feigenbaum et al, 2013). As such they require a reading between the lines which can open the research up to critiques of researcher insider/outsider bias. Whilst such factors may impact any form of social science research employing standard methods of inquiry (Flyvbjerg, 2001), there are others that are more closely associated with researching eventful protest and dissent, adding more clouds to an already troubled sky.

Both the activists and those that represent forces mobilised to 'contain' manifestations of protest have a vested interest in projecting, and protecting, the world view of which they are a part. For understandable reasons (Monaghan and Walby, 2018; Schlembach, 2018) the groups (such as campaigning organisations and security/policing services), whose physical 
presence at protests is the most overt articulation of such events, in the mediated imaginary of them, are wary of people asking a lot of questions (Mowatt, Forthcoming). Engagement with the context within which the research is undertaken is problematised by factors the participant and/or the researcher implicitly foreground and background in their apprehension of the other actor. Whilst there may be no paradox in holding a position of activist/academic (Higgins-Desbiolles, 2010) the researcher may brings with them assumptions around norms and behavioural routines that, consciously or otherwise, they may lapse into when articulating their questions or interpreting a participant's response. Such Goffmanesque foregrounding and backgrounding (Goffman, 1963) operates as a limitation to the rigour of the research. Comparable arguments can be made for participants that might be considered 'bystanders' to the event.

Chesters (2002) has suggested that attempting to adopt a stance of academic neutrality raises several ethical concerns, especially associated with how we establish the locus of knowledge production. Adopting an ethics of engagement, he suggests, would move away from considering social movements as an object from which knowledge can be produced; instead it would acknowledge the capacity of such groups to be valued as producers of knowledge in their own right. Such a position resonates with the critical pedagogy of Paulo Freire (1996) and Ernest Boyer's (1997) conceptualisation of engaged scholarship; both emphasised co-creation and collaboration over pedagogic and epistemic colonisation (Holland et al, 2010). In their approach to researching protest camps, Feigenbaum et al (2013) attempted to address some of these concerns by adopting a form of photo-elicitation led group discussions, these camp fire chats were set within a context convivial to participants. Using images that had been gathered from a variety of material and digital 
sources, they deployed a number of game-like activities within the context of chats around a camp's communal fire, utilising their resources to stimulate affective memories and conversation ${ }^{\mathrm{ii}}$. The use of images also facilitated communication between researcher and activist, where neither shared a common language. Whilst the approach offered opportunities for generating fresh insight into the imaginary of dissent within the setting of protestful occupation, it does require a careful balance being struck between congeniality and a cooler distance, as the researcher is still required to seek some level of impartiality.

Though discussing a different context, one that is aligned to the negotiation of policy change, Teghtsoonian (2016) has argued that social inquiry which adopts a singular framework risks narrowing or closing down possibilities for research and analysis. This is not the same as advocating a mixed-method approach. The limitations that have been mentioned already would not, necessarily be overcome by adopting a mixed-methodology, if anything those limitations would be reproduced and compounded by becoming even more deeply entrenched. What is required, she suggests, is a reflexive, ongoing, dialogue. Echoing Dorothy Smith's feminist activism (2007), she calls “...researchers to a practice of reflexivity in considering the political effects of the methodological choices (they) make" (Op.Cit. p. 331). At this point it is worth considering the perspective critical event studies (CES) can bring, as a conceptual orientation, to this discussion.

CES is an emerging sub-field of event studies which, according to Spracklen and Lamond (2016), begins with a problematisation of the referent - 'event'. In their words; 
"At its most basic level we define event as 'that which intervenes the mundane'. We understand that such interventions will be contested by some of those impacted by them, and that they are never simple, surgical-like incisions; if anything, they are more like a ragged laceration with consequences far beyond those of the location of the wound." (p. 9)

A central characteristic of 'events', CES argues, is disruption and contestation. It is through approaching events from their wider context and grasping their essentially disruptive and contested character that what becomes construed as the event is brought into focus (Robertson et al, 2018). Through reflexively examining the multiplicity of the disturbances that are drawn together as the event, asking how they are being drawn together (by whom and for what purpose), and in what way(s) are they being mediated, what becomes construed as 'the event' emerges (Finkel et al, 2018). Such multiplicity shifts the emphasis away from conceptualising event as singular to what can be more usefully thought of as an evental (Badiou, 2017) spatio-temporal site. It is through confronting those imaginaries, discourses and discursive practices that what comes to be constituted as the 'event' can be studied.

If 'event' is to be constituted through a reflexive exploration of what might be considered the evental site what about the spatio-temporal 'event' that constitutes the site of research? From such a perspective, inquiry becomes an activity that constitutes itself through an iterative and reflexive process. However, it is not simply an activity, but one where adopting an evental approach to research acknowledges that it needs to exhibit characteristics that resonate with its contested and disruptive outlook. As such it is 
consistent with Teghtsoonian's (2016) and Smith's (2007) position; to consider the political effect of one's methodological choices. It thus forms part of a family with other critical orientations, which cut across tourism, leisure and events research. Consequently, the division between knowledge gatherer and contributor, between insider and outsider, subject and object (etc.), can be confronted with knowledge being co-created and shared, and thus able to carry the potential to profoundly impact the agents commonly denominated as researcher and participant. Thus, appropriate methodological approaches to investigating the imaginaries of dissent and protest, within a CES, would need to be disruptive (exposing the discursive practices hidden in the mundane and routine of daily life), and adaptive (so that they can engage iteratively and reflexively, whilst challenging the 'researcher', the 'participant' and the presumed boundaries between them). But what can be construed as disruptive or adaptive methodologies, and how were such terms understood within the disrUPt project?

\section{$\underline{\text { Adaptive and Disruptive Methodologies }}$}

Adaptive Methods

Adaptive methodologies were first proposed by James Kay in the mid-90s (Kay and Schneider, 1994) as a means of developing an understanding of the complexity exhibited in the interplay between human (social) systems and the environment (ecology) in which such systems were located. Working within an arena of environmental systems management, Kay and his colleagues argued that such an eco-social systems approach was required if we are to grasp how "...the nexus in which ecological understanding and sociocultural preferences met and interfaced with policy makers and managers" (Waltner-Toews and Kay, 2005. p.39). 
This "diamond schematic", as they called it, embraced a holarchic approach (i.e. one where the parts and whole of the system are functionally inseparable and, to an extent, indistinguishable (Koestler, 1969)) that characterised such eco-social systems as resilient, whilst also exhibiting integrity and self-organisation (Kay et al, 1999). Waltner-Toews and Kay (2005) argue that investigating such systems requires an adaptive rather than fixed methodology because;

"Within the dynamics of eco-social complexity and the uncertainty this generates, we are faced with finding our way through a foggily perceived landscape rather than charting a scientifically determined course to a known end point." (p.39)

The complexity, or fogginess, of eco-social systems emerging from the multiplicity of “...socio-ecological stories, pictures and system descriptions" (ibid, p. 45) articulated by the agents contributing and co-constituting the system itself. In striving to understand such complexity they go on to propose an approach called AMESH (Adaptive Methodologies for Eco-social Sustainability and Health). which can move beyond fixed, singular (or mon-ocular) perspectives by encouraging researchers and practitioners to;

“...look for and understand system feedback and the emergence of selforganization. The iterative nature of this process and its multi-ocular assessments mean that the unpredictability and uncertainty of eco-social systems, with the potential for dramatic flips, can be more easily accommodated than in more conventional approaches." (Waltner-Toews \& Kay, 2005. p.49) 
Beyond the field of environmental systems management, adaptive methodologies that derive from the AMESH framework have also been used in broader sociological theory. Armitage et al (2008), argue that incorporating adaptivity is essential if one is to truly consider the impact of an external environment that is in a process of constant change. Cherednichenko and Godlevsky (2015) develop this further. They suggest that adopting adaptive methods, that can adjust as new sources of data become apparent, avoids many of the limitations of fixed methodologies within self-regulatory and open systems where, as Penn (2016) has put it, “...we must be prepared to take action without full system understanding" (p.26).

Because of the complexity of the relations within and between parts and their environment (Koestler's principle of the holarchic, 1969) and the constant change of that environment, adaptive methodologies thus emphasis the use of more than one approach (Waltner-Toews, multi-ocular-ism) that can be adjusted as new data is made available. This should be understood as a realistic response to the fluidity of the eco-social systems within which participant and researcher are located, and not as a means of triangulation, as a mixedmethods approach might.

\section{Disruptive Methods}

As we found in our consideration of adaptive methods, disruptive methodologies can, to an extent, be connected to systems theory. Hodgson and Midgley (2015) have suggested that the definition of any system we are investigating is a function of the multiplicity of its 
stakeholders. Such systems, they maintain, are not a fixed object but mutable, evolving, and adaptive. Through critique (i.e. disruption) of its boundaries, both internally and between it and other systems, the system can confront its ambiguities and assumptions whilst clarifying where power lies; how it is operating, and in whose interest it is working. Analogous to this, Lamond (2018) has argued that agents, whether individual, institutional or otherwise (e.g. a social movement), contributing to the constitution of an event of protest can, with varying levels of ontic and epistemic attachment, be construed as stakeholders within an open system. That is, they can be construed as advocacy coalitions (Sabatier and Weible, 2007) associated with policy positions around an issue. Jones and Jenkins-Smith (2009) argue that the mobility of agents, from one coalition to another, depends on the strength of those ontic and epistemic connections. All other factors being equal, if someone has a weak connection to a coalition, they may defer to participation through an online campaign, whilst an agent with strong ontic and epistemic ties will be motivated to travel (as an activist tourist) to a site, or sites, associated with campaigning. Here we find resonances with Pezzullo's (2009) toxic tourism. It is by disrupting a coalition that we can, in principle, gain insight into those system factors highlighted by Hodgson and Midgley (2015).

Zielińska et al (2011) and Kowzan et al (2014) have explored the use of disruption as a political pedagogic device by social movements, as well as a pedagogic methodology. Their studies focus on the use of direct intervention, by activists, in lectures halls in Poland between 2009 and 2013; reflecting on the consequences of such disruption and "...on the learning of various actors" (Ibid, p.297). Zielińska et al (2011) analyse one case study lecture intervention as: 
“...a configuration of three subjects: the speaking one (the lecturer), the listening one (the audience) and the (out)standing one, that is, the protesters. We [argue] ...that the activists change the communication between the lecturer and the audience by their protest. They provoke and surprise the other two subjects and point to ambiguities in the world, and in the lecturer's message, showing their resistance to the ideology behind it." (p.257-258)

As such the intervention becomes both a method for the exposure of power and potential pedagogy, as it can present an opportunity for shared learning, growth, and development. At a more local and more overtly pedagogic level, Bastian (2015) has employed disruptive techniques to make visible the regimes at work in choosing texts within the classroom. Such flipped approaches to learning, as they are commonly termed, are gaining increasing traction at all levels of learning (Reidsema et al 2017).

What is common across these and other approaches to disruptive methods is the way they expose discursive routines whilst offering an opportunity, as Walker (2015) puts it, to blur formal and informal space. As such they challenge the boundary between 'insider' and 'outsider' and, ultimately, they can work to dissolve that binary. In her analysis of cultural resistance Sarah Kanouse (2004) suggests that such disruptive approaches can reshape discursive, physical and relational spaces, and facilitate the reimagining of them, i.e. disruptive methods present us with an opening where fresh imaginaries can emerge. Disruption permits a Deleuzian deterritorialization (Deleuze, 2014) that enables the recontextualization and formation of unexpected connections. However, as Halvorsen (2015) has pointed out, disruptive methods cannot offer a fixed approach; to do so would 
mitigate their capacity to evoke the affects they seek. Instead, any such research approach must operate "...against-and-beyond itself, [in] a constant struggle to overcome any form it takes" (p.467). Consequently, if a method is to be truly disruptive, it must always-already exhibit some form of adaptivity.

\section{Adaptive and disruptive methods in the disrUpt project}

Having considered the background to adaptive and disruptive methods it is imperative we now consider how the disrUPt project approached them, and how they emerged within the project. As mentioned at the beginning of the paper, one of the purposes of the disrUPt project was to explore methods that could facilitate a deeper understanding of the imaginaries of dissent associated with events of protest.

Prior to the commencement of the project the author, as principle investigator ( $\mathrm{PI})$, instigated a series of meetings that drew together members of the research team, as listed earlier. Through the team's own connections, representatives from a number of regional small-scale and independent cultural agents as well as activists from a range of social movements, based in and around the university's home city of Leeds (West Yorkshire - UK), were also invited. The cultural organisations included an independent arts cinema, an architectural practice with a primarily regional footprint, and an independent film festival curator. The social movements covered a variety of activist interests, including environmental activism; anti-war movements; LGBT+ campaigners and others. At the first meeting the conversation focused on the form the research could take. Whilst the core aim, that of trying to find ways of uncovering the diverse imaginaries associated with the practice of events of dissent that took place in an urban context, was maintained, the research 
approaches to be adopted were openly discussed and allowed to appear organically from the dialogue between all the meeting's participants. Central to the steering of that meeting was a commitment, by the PI, to draw on the experience of non-academic participants in articulating approaches that would resonate with their engagement with the city, both as a physically present space, but also as a spatial imaginary. Having established a loose framework of projects at that first meeting, academics were attached to them depending on their personal strengths and interests. Subsequent meetings took the form of reporting on the progress of the diverse projects initiated.

The idea of disruption as an orientation for the research programme emerged quickly. Whilst central to the PI's construal of 'event', they were careful not pre-impose their own perspective on the group. However, 'disruption' still emerged in the dialogue of that initial meeting. 'Disruption', echoing the formulation of Kanouse (2004), was found to lie at the heart of practice for both the cultural and activist agents present. The framework of methods adopted, which will be outlined shortly, were intended to disrupt the imaginaries of all participants (including those of the researcher) so that they could be more easily articulated and, in a supportive way, something upon which the extended team could reflect. This, to a degree, resonated with the work of Zielińska et al (2011) and Kowzan et al (2014), in their suggestion that disruptive methods also represented a form of activist pedagogy. Given this shared orientation, the group agreed to change the project's title from 'Creativity, protests and the city' to 'disrUPt'.

Bearing in mind Halvorsen's (2015) warning that disruptive methods should occur in a constant struggle to overcome whatever form they take, some element of adaptivity was 
also felt to be required. Koestler's holarchic principle of the complex inseparability of part and whole in an open system, would suggest the research approaches to be explored would also need to incorporate elements of reflexive adaptability. However, the degree to which this should be incorporated within the project did not receive a consistent level of support. Consequently, the range of methods to be adopted included differing degrees of adaptiveness. The next section will outline the four approaches explored by the disrUPt project and the extent to which they exhibited adaptive and disruptive methods.

\section{The disrUPt Research Programme}

The four approaches adopted as part of the disrUPt research programme were: the creation of an artefact as a device for urban intervention; use of augmented film screenings; a film making workshop; and the production of a safe and structured environment, where participants, usually in a confrontational relationship during periods of protest, were able to meet and share their imaginaries of dissent. The order presented here follows that in which they were rolled out during the running of the project, which ran between October 2016 and November 2017. Each will be taken in turn and how they were delivered discussed.

The Kino-Cine Bomber: Disrupting Urban Space

Created by postgraduate architecture students from the University of Sheffield (South Yorkshire - UK), with the support of the Leeds based architecture practice Group Ginger, the Kino-Cine Bomber is a bicycle-based cinema device intended to "...re-imagine disused buildings and obsolete urban infrastructure (as a space) for public leisure" (Group Ginger, 
2017. NP.). Drawing on principles inspired by both the praxis of détournement (a form of cultural re-routing, or hijacking), initiated by the Situationists, and the spatial philosophy of Henri Lefebvre, the use of the projected moving image is deployed by the device to reimagine urban space through subtraction. For example, in Coventry (West Midlands - UK) it was deployed to 'daylight' the path and flow of a river hidden by present urban development, it thus subtracted from the contemporary context so as to re-inscribe the river into the urban space, thereby revealing a presence through the imaginary of absence.

Based on a 'Christina' (A form of Danish freight carrying bicycle), the Kino-Cine Bomber is comprised of, "...an added wooden tower to elevate a 2000-lumen (digital) projector; a car battery powers the projector, 50-watt sound system, and radio transmitter (for anyone wishing to listen in via radio)." (Ibid-NP) Figure 1 shows one the Kino-Cine Bomber in operation in Coventry, making visible ('daylighting') a former space of public entertainment in what is now an area dominated by new office developments.

$$
<<\text { Insert Figure } 1>>
$$

Figure 1: The Kino-Cine Bomber

(Source: Simon Baker/Re-Activist Studio. Used with permission)

The process of subtraction ('daylighting' and re-imagining), produced through the projections of the device, are intended to disrupt the imaginaries of space, creating what Guy Debord might have described as the undermining of the commoditisation of the 'spectacle' through the creation of rebellious artistic situations (Debord, 2011). The intention is to use the kino-cine bomber on a series of sorties (as those that worked on 
creating it have referred to its deployment) around Leeds, whilst evaluating the impact of its use through the response of those reacting to its intervention. So far, the artefact has only undertaken trial sorties in Coventry, though steps to secure its use in Leeds are currently being planned.

Augmented Cinema: Disruptive Film Screenings

Between November 2016 and October 2017, the disrUPt project screened around a dozen films in five venues. Screenings took place in a variety of spaces in and around Leeds. Those spaces included venues designed for cinematic presentation (an independent cinema close to the project's home university) to non-traditional and pop-up venues (including a municipal building; a disused church converted into an arts centre; a small event space attached to a city centre café, and an independent venue close to the city centre's railway stations that is used mainly by emergent unsigned bands). The themes covered by the films shown, which were predominantly documentary films or the product of activist film makers, were initially suggested within the pre-project meetings discussed earlier. As regards the specific films screened, these emerged through dialogue between the activists on the team, the venue host, an independent film events coordinator, the $\mathrm{PI}$, and what could be made available. The film selected for each venue was only finalised between one screening and the next, rather than pre-set at the start of the series. A central element of each screening was how it was to be 'augmented' (i.e. disrupted), adapting each screening to resonate with the films theme and possible attendee reaction. How the screening was to be disrupted varied from one presentation to the next. Before outlining some of the key elements of 
disruption that were used it is worth taking a small detour to establish the background to augmented cinema.

Augmented cinema draws on elements of what has become known, in more commercial circles, as 'Live Cinema'; which is defined by Atkinson and Kennedy (2016) as:

“...a cinema that escapes beyond the boundaries of the auditorium, whereby film screenings are augmented by synchronous live performance, site-specific locations, technological intervention, social media engagement, and all manner of simultaneous interactive moments, including singing, dancing, eating, drinking and smelling" (p. 139).

However, it supplements this with practices akin to those established by 'third cinema' (Solanas and Getino, 1969), which began to appear as a form of underground film making and sharing in Latin America during the 1960s. 'Third cinema' identified films that were overtly political, that carried an explicit political message, and screened them in such a way as provoke debate. They were, as Presence (2013) argues, films made and presented to be 'detonators' of discussion, often in non-traditional spaces, that would often target marginalised issues and communities. As well as post-screening panel-led discussions, which are a common practice in the showing of documentary and 'politically' motivated films, the disrUPt screenings incorporated disruptive elements. They included; an impromptu book readings, apparently spontaneous performances by community choirs, a pay-as-you-feel buffet of rescued foodiii, an unannounced demonstration of placard bearing protesters walking through and round the audience prior to the screening. One screening was located 
in a space where the attendees had to first navigate through an audience for a completely different event. The augmentations were decided between screenings, adapting to the theme and the audience reaction to the previous intervention. Figure 2 was taken outside one of the screening venues (the converted church). It shows members of the Commoners Choiriv just before they processed through the audience, carrying banners and singing their own brand of political music.

$$
<<\text { Insert Figure } 2>>
$$

Figure 2: The Commoners Choir prepares to disrupt a film screening.

(Source: The authors)

Adaptivity was central to keeping the screenings unique and responsive, whilst disruption served multiple purposes. Similar to Debord's positioning of situationist interventions, mentioned earlier, the playfully rebellious creative disruptions helped establish an environment where those who wished to engage in discussion, following the film, could do so in a supportive, though candid, manner (the disruptions permitting an almost 'anything goes' setting). It is planned to follow up this part of the project with a number of lightly structured interviews with people who self-selected to participate in that part of the project at the end of the screenings. The disruptive elements within the cinematic presentations will, in those instances, also act as a point of shared memory through which rapport, trust and, it is hoped, participant integrity, can be assured. 
Working with the Liverpool based new media arts organisation First Take, the disrUPt project set up a short film making course for women, from what might be considered marginalised communities in West Yorkshire. Participants were recruited on the basis of the provision of an opportunity to learn more about film making Several community organisations in the region that worked with women from $\mathrm{BAME}^{\mathrm{v}}$ communities were approached, including some working with refugees and asylum seekers. Nine women signed up for the course, which ran for two blocks of three days, over a fortnight, crossing July and August 2017. The orientation of the workshops drew on the pedagogic principles of Paulo Freire, who argued "[t\}he oppressed must be their own example in the struggle for redemption" (Freire, 1996 p.54). Though each participant learnt how to make and edit film through the direct intervention of one with expertise in those skills, the created film had to be on a topic that all participants agreed was meaningful to them. This flipped the expertise away from the person conventionally designated as 'the teacher'. Whilst that person remained in role as facilitator, imparting technical knowledge, she also acquired the position of student/learner as she grew to discover more about the issues the participants confronted, how they felt about articulating their concerns, and how they managed those tensions in their daily lives. The skills developed were, as a consequence, directly connected to the empowerment of the participants in articulating their concerns. Figure 3 is a still from the film, it is a representation of some of the domestic violence a number of the participants had experienced.

$<<$ Insert Figure $3>>$

Figure 3: Film still

(Source: First Take - www.firsttake.org.uk. Used with permission) 
The finished film, which has no name, runs for a little over 7 minutes and addresses issues of gender equality and domestic violence (In the form of both emotional and physical abuse). In conversation with the $\mathrm{PI}$, after the completion of the film, the workshop facilitator commented on how moved she was by the experience of working with the group, and how much she had learned from the participants. Not just about the violence they faced but how the precarity of their situation (many were seeking asylum in the UK) also impacted that experience, and their capacity to share it with others. Testified by the film's content and anecdotal accounts emergent from conversations with them and the community workers through which they were connected, the female participants also seemed to develop bonding attachments that extended beyond the workshops. With some of them now engaging with other forms of activism, and a few interested in developing their community film making skills further.

Sadly, in part a product of the women's trepidation around the film's content and their appearance in it (Which has arisen from a combination of, for some of them, uncertainty around their current residency status and, for others, concerns associated with the possible repercussion of some family members 'getting wind' of their involvement.), they have stated that the film should not have a public screening. To date the film has had a small, closed, screening, to an invited audience; this was in November 2017. Audience reaction was very positive and supportive. Whilst only one of the group spoke, before the presentation, she spoke with passion about the opportunities the programme had given them all, and the importance of the messages they were trying to communicate through the film. The PI has agreed that future presentations of the film will only be with the agreement 
of the majority of those people that participated in its making, both in front of, and behind, the camera.

Critical Conversations: Disrupting the focus group.

The final approach was the creation of a series of three opportunities for conversation. These took the format of focus group meetings; however, though this was the least disruptive of all the approaches, the meetings diverged from those forms of focus group that seek some level of demographic comparability or strive to obtain a degree of consensus around a topic (Barbour, 2018; Krueger, 1988). Demographics was not a consideration, nor was a consensus sort. Given the tension between the camps represented at the meetings contestation was anticipated, not agreement; consequently respecting participants right to their own position, at the meetings, needed to be managed carefully. Whilst actual participants had not been targeted, the character of their connection to events of protest had been. It was organisations and agencies that were approached through their association with protest; participants volunteered through those networks. Each meeting lasted around 2 hours, and the same people were invited to each meeting. Given the work commitments of a number of the invitees, the meetings were scheduled to run at roughly monthly intervals and ran between late April and early July 2017. Despite this, it was not the case that all those contributing could attend every meeting. Over the three sessions we had participants from; activist groups (both young members and those that might be considered veteran campaigners); local councillors; leaders in the regional business community; people with a direct connection to mass media (broadcast and print based); city-based securitisation services (though a representative from the police was not forthcoming), and 
people with a direct connection to either legal services, or human rights law. As such, the group was composed of people who, whilst connected to events of protest within a city context, did not necessarily share a sympathetic perspective on protest and the practices of social movements. All participants were aware of the composition of the group but were not, at first, aware of the relationship others had to the topic being discussed. Obviously, this became apparent as the first meeting progressed, but it did not form a presupposition attachable to any particular individual, before the conversation began.

In the briefing prior to each group discussion, issues of respecting everyone's right to speak, to have a view that was to be acknowledged as legitimately their own, and that everything said in the room was strictly confidential, were addressed. All participants were given gender neutral names, and only those names were to be used in the conversation. This made disruption and adaptivity central to each participant's participation, while it also formed part of how the conversations developed over subsequent meetings. The first conversation had an open brief, with a loose framework of discussing the relationship between protest and the city. Following the end of session wind-down, options around the structure for the following session were considered. A variation on Feigenbaum et al's (2013) campfire chats approach, mentioned earlier, was approved by the participants. It was agreed that all attending would bring an artefact they associated with dissent and protest, which would provide the opening stimulus for conversation. It was also suggested that the PI would bring a number of images, taken from online sources, to stimulate debate, if 1) nobody brought anything or 2) conversation dried up quickly. It transpired that this was the longest session, with a number of participants carrying on the conversation in a bar after we had been asked by the University's security staff to vacate the building. At the final session it 
was agreed to share a text that the PI had mentioned in the first meeting, which would be circulated and used as the focus of the final discussion. The text was Chapter $3^{\text {vi }}$ of Jacque Rancière's book "Hatred of Democracy" (2014).

Anecdotally the three meetings proved successful in building bridges between diverse world views. As a framework, they could, in principle, lay the foundations for developing a future programme that seeks a shared vision for how such stakeholders can negotiate the use of city spaces around events of protest. To facilitate data capture, the conversations that took place over the three meetings were audio recorded and transcribed.

\section{Reflections on the disrUPt Research Programme}

Each of the four approaches explored by the disrUPt project contained, to varying degrees, adaptive and disruptive elements. In all cases, those elements were a central part of the research experience for both participant and researcher, and as such permitted articulations of multiplicity which CES characterises as central to its construal of 'event'. Thereby reflecting an examination of the imaginary of dissent, through an orientation that construes the research project as evental. Additionally, in acknowledging such multiplicity, the project highlighted hybridity within adaptive and disruptive methods as something that moved beyond mixed methods. Implicit within such methodologies is the desire to achieve some form of convergence on a single world view (Robson and McCartan, 2016). As a form of militant methodology (Halvorsen, 2015), disruptive and adaptive methods differ in that they mark a holarchic (Koestler, 1969) turn towards the traditional binaries of subjective/objective; academic/practitioner; or insider/outsider, through a problematisation 
of the ways in which they are being constructed through the evental site of research:

operating, as Halvorsen suggests, “...against-and-beyond itself” (Op.Cit. p.467).

However, as the project developed, it became apparent that the approaches encountered several limitations with regards to the practicalities of their deployment and viability, as well as their conceptual legitimacy.

All four piloted methods required substantial partnership working, which had a significant impact on the scale and reach of the programme. Whilst attempts were made to extend the project beyond the one urban environment, which would have facilitated a greater opportunity to explore potential conversations between culturally diverse imaginaries of dissent, this was only achieved with the Critical Conversations element of the programme. Even in that instance, the partnership was not as straightforward as it had been hoped. Two key factors made partnership cooperation and development difficult. First, was the limited time that trust had to develop between all those involved in the programme's delivery; not just at an individual level, but also institutionally. On a one-to-one basis this, for the most part, worked relatively well, but institutionally it became more problematic. Trust as either a sharing of power or the negotiated give and take within a more nuanced power relationship (Baier, 1986) proved challenging when working with what may be construed as regionally recognised brands. This was not equivalent to the size of the organisation but, to an extent, its visitor/user reputation. Consequently, relating this to the second factor, we found partners reticent around taking, or absorbing, what they encountered as risk. For example; we encountered this in wariness around granting permission for a Kino-Cine Bomber sorties. With some potential hosts unsure of how attracting visitors to what might otherwise be 
considered an unglamorous space, would impact their impression of the wider location. Some venues exhibited a degree of caution around offering to host a film to be screened. The film "Just Eat It", about food waste, was rejected by several potential spaces, as they were unsure how attendees would subsequently view the hosts food policy. Such matters made negotiations time consuming, with programme delivery resting, at times, only on a partial indication that the partner was actually as committed to the delivering the output in the format the project had requested. The disparity between the disruptive and adaptive approach being developed by the research team, and some of the lag emergent from some of the careful negotiations with the partner relationships, added, an inertia to how some elements became articulated.

As well as these practical problems there was also a key question around how to extract and analyse data from the approaches that have been trialled by the disrUPt project. Whilst the focus of this paper has been on the research methods used, part of the evaluation of the effectiveness of those methods also considered how data could be extracted from them. However, to date, very little of that work has been undertaken. This is a key limitation in the project as a whole, and one that must be addressed if it is to progress. DisrUPT was established to explore methodologies appropriate for engaging with the diverse imaginaries of protest articulated by agents, whether individual activist tourists; organisations; social movements or institutions, associated with events of dissent. Although the adoption of disruptive and adaptive methodologies were found to be successful in facilitating the articulation of those imaginaries, the proposed routes anticipated for capturing and analysing data from those methods did not exhibit characteristics consistent with the disruptiveness and adaptiveness of the interventions themselves. Both Jackson (2008) and 
Cashman et al (2008) in their discussion of community based participatory research (CBPR) point to such limitations within much participatory research. For the most part, the techniques that have been suggested, whether anchored is some form of grounded theory, narrative or thematic analysis still rely on the standard tools of social science research critiqued earlier. As such they undermine one of the ultimate objectives of the project; to examine the imaginary of dissent from a perspective that is closer to that of individual experience. Methodologically therefore, whilst contestation is addressed it does not, as Torre et al (2012) argue, confront "the deep and knotty relations of privilege and injustice" (p.179) inherent in researching from the outside - in. Jackson (2008) and Nind's (2011) approach to participatory qualitative data analysis may, through the seeking of narratives and themes in collaboration with non-academic research partners, offer a way of managing such concerns. A possible limitation is that, in contrast to the groups participating in the disrUPt project, both Jackson and Nind worked with communities where the world view of their participants contributed to their coherence as an identifiable group; many of those that contributed to the disrUPt project were in direct contestation with each other. Even within a loose coalition that could be associated with a specific concern, factional differences in world-view, on approach, language, and intended impact were commonplace. However, the structural embedding of participant engagement in the process of data capture and analysis that Jackson (2008), Nind (2011) and, Torre et al (2012) recommend, could support the emergence of a disruptive and adaptive toolkit for participant led data analysis. Such considerations will be borne in mind as the project proceeds. While the detail of how a disruptive and adaptive approach is to reach into those corners of its inquiry is yet to be ascertained, the need to incorporate some form of participatory data analysis is unquestionable. 


\section{$\underline{\text { Conclusion }}$}

There is an old English proverb; the proof of the pudding is in the eating. To date, the disrUPt project is still at an early stage. If it were a loaf of bread; whilst it may be in the latter stages of proofing, it is yet to be baked. The primary purpose of the disrUPt project was to explore methodologies appropriate to studying the imaginary of dissent, from a perspective that was close to that of individual experience, within activist mobilities and activist tourism. In that it was successful. However, it cannot claim to have succeeded fully if it does not also produce some explicit findings and identifiable conclusions that are drawn from the approaches it has trialled. In order to address that concern the programme has slowed, allowing it time to explore and review participatory qualitative data analytic approaches, ones that can also adopt a disruptive and adaptive perspective on data capture: disrUPt is far from over.

The partnerships that were central to the delivery of the project are still in place and lay a substantial ground upon which disrUPt can grow, and new research programmes can emerge. Over time, the factors of trust and the capacity to take and absorb risk, through the partnering relationships that have been built, are extending and deepening. Such enhanced relationships bode well for future, further, exploration of approaches to the study of the imaginary of protest and dissent. There are plans for the Kino-Cine Bomber to take more sorties. Venues and film event programmers are showing increased interest in the use of augmented screenings. Members of the research team have been approached by other community partners who have expressed an interest in film making projects. Conversations 
with colleagues at universities in Sao Paulo (Brazil) are progressing around how a critical conversation framework can have the potential to establish spaces where stakeholders with contested imaginaries of the city can discuss the value and place of dissent within their urban context. Such an approach carries resonances with the findings of de Frantz's study of the planning of the Museumsquater in Vienna (de Frantz, 2018), where she concludes that progress was achieved when “...the governing consensus was transformed...through an open, inclusive and contentious process of discursive interaction" (pp. 502). If fruitful, it could lead to policy changes that result in negotiated moments of dissent within the spatial fabric of the city, welcoming the activist tourist and contributing to the destination's visitor narrative.

\section{$\underline{\text { References }}$}

Amsden, B.L.; Stedman, R.C. and Kruger, L.E. (2010) The creation and maintenance of sense of place in a tourism-dependent community. Leisure Sciences. 33(1), 32-51.

Armitage, D., Marschke, M., and Plummer, R. (2008). Adaptive co-management and the paradox of learning. Global Environmental Change, 18(1), 86-98.

Atkinson, S. A., \& Kennedy, H. W. (2016). Inside-the-scenes: The rise of experiential cinema. The Journal of Audience and Reception Studies. 13(1), 139-151.

Badiou, A. (2017) Conditions. Trans. S. Corcoran. Bloomsbury Academic, London.

Baier, A. (1986) Trust and antitrust. Ethics 96(2), 231-260.

Barbour, R. (2018) Doing Focus Groups. Sage, London. 
Bastian, H. (2015). Capturing Individual Uptake: Toward a Disruptive Research Methodology. In Composition Forum (Vol. 31). Association of Teachers of Advanced Composition. Online at: $<<$ https://eric.ed.gov/?id=EJ1061545 >> Last accessed 30 th July 2018.

Bevington, D., \& Dixon, C. (2005). Movement-relevant theory: Rethinking social movement scholarship and activism. Social movement studies, 4(3), 185-208.

Bianchi, R. V. (2009) The 'critical turn'in tourism studies: A radical critique. Tourism Geographies, 11(4), 484-504.

Boyer, E.L. (1997) Scholarship Reconsidered: Priorities of the Professoriate. Jossey-Bass, San Francisco.

Brin, E. (2006). Politically-oriented tourism in Jerusalem. Tourist Studies, 6(3), 215-243.

Buda, D. M., and McIntosh, A. J. (2013) Dark tourism and voyeurism: tourist arrested for "spying" in Iran. International Journal of Culture, Tourism and Hospitality Research, 7(3), 214-226.

Buncombe, A. (2017) March for Science: Thousands march in 500 cities to protest Donald Trump's 'rejection of science'. Published in the Independent $22^{\text {nd }}$ April 2017. Online at: <https://www.independent.co.uk/news/science/march-for-science-earth-day-marchprotest-donald-trump-science-rejection-a7696816.html> Last accessed: 30 $0^{\text {th }}$ July 2018.

Cashman, S. B., Adeky, S., Allen III, A. J., Corburn, J., Israel, B. A., Montaño, J., ... \& Eng, E. (2008). The power and the promise: working with communities to analyze data, interpret findings, and get to outcomes. American journal of public health, 98(8), 1407-1417.

Castoriadis, C. (1993) World in Fragments: Writings on Politics, Society, Psychoanalysis and the Imagination. California, Stanford University Press. 
Castoriadis, C. \& Ricoeur, P. (2017) Dialogue on history and the social imaginary. Trans. S.

Davidson. In S. Adams (Ed.) Ricoeur and Castoriadis in Discussion. Rowman \& Littlefield International, London. pp. 3-20.

Cherednichenko, O., and Godlevsky, M. (2015). A new methodology of complex systems management. Online at: <http://repository.kpi.kharkov.ua/handle/KhPI-Press/15685> Last accessed: $30^{\text {th }}$ July 2018.

Chesters, G. (2002). [Review of A. Starr (2000) Naming the Enemy: Anti-Corporate Movements Confront Globalization. Zed Books, New York.] Organization \& Environment. 15(2), 214-217.

Debord, G. (2011) Comments on the Society of the Spectacle. Trans. M. Imrie. Verso, London.

De Frantz, M. (2018) Tourism marketing and urban politics: Cultural planning in a European capital. Tourism Geographies. 20(3), 481-503.

Deleuze, G. (2014) Difference and Repetition. Bloomsbury Academic, London.

Dixson, C. (2001) Finding hope after Seattle: Rethinking activism and building a movement. Online at: http://theanarchistlibrary.org Accessed: $28^{\text {th }}$ May 2019.

Feigenbaum, A., McCurdy, P., \& Frenzel, F. (2013). Towards a method for studying affect in (micro) politics: The campfire chats project and the occupy movement. Parallax, 19(2), 21-37.

Finkel, R.; Sharp, B.; Sweeny, M. (2018) Accessibility, Inclusion, and Diversity in Critical Event Studies. Abingdon, Routledge.

Flyvbjerg, B. (2001) Making Social Science Matter: Why social inquiry fails and how it can succeed again. Cambridge University Press, Cambridge.

Freire, P. (1996) Pedagogy of the Oppressed. Trans. M.B. Ramos. Penguin Books, London. 
Glynos, J. and Howarth, D. (2007) Logics of Critical Explanation in Social and political Theory. Routledge, Abingdon.

Goffman, E. (1963) Behaviour in Public Places: Notes on the social organisation of gatherings. The Free Press, New York.

Group Ginger, (2017) Urban subversion and mobile cinema. Online at: <http://www.groupginger.com/blogs/2018/01/04/urban-subversion-and-mobilecinema-leisure/> Last access: 30 ${ }^{\text {th }}$ July 2018.

Hales, R., Dredge, D., Higgins-Desbiolles, F., \& Jamal, T. (2018). Academic activism in tourism studies: Critical narratives from four researchers. Tourism Analysis, 23(2), 189-199.

Halvorsen, S. (2015). Militant research against-and-beyond itself: critical perspectives from the university and Occupy London. Area, 47(4), 466-472.

Hercbergs, D. (2012) Narrating instability: Political detouring in Jerusalem. Mobilities, 7(3), 415-438.

Higgins-Desbiolles, F. (2010). In the eye of the beholder? Tourism and the activist academic. In P.M. Burns, C.A. Palmer \& J.M. Lester (Eds), Tourism and Visual Culture, pp. 98-106. CABI, Wallingford.

Hodgson, A., and Midgley, G. (2015, January). Bringing Foresight into Systems Thinking: A Three Horizon Approach. In Proceedings of the 58th Annual Meeting of the ISSS-2014 United States Online at <http://journals.isss.org/index.php/proceedings58th/article/view/2278> Last accessed: $30^{\text {th }}$ July 2018 .

Holland, D., Powell, D. E., Eng, E., and Drew, G. (2010). Models of engaged scholarship: An interdisciplinary discussion. Collaborative Anthropologies, 3(1), 1-36. 
Jackson, S. F. (2008). A participatory group process to analyze qualitative data. Progress in community health partnerships: research, education, and action, 2(2), 161-170.

Jones, M. D., and Jenkins-Smith, H. C. (2009) Trans-subsystem dynamics: Policy topography, mass opinion, and policy change. Policy Studies Journal, 37(1), 37-58.

Kanouse, S. (2004). Ungrounded Opposition: Cultural Resistance as Virus (Doctoral dissertation, School of Art and Design, University of Illinois, Urbana-Champaign). Online at: <http://www.readysubjects.org/writing/kanouse_mfathesis.pdf> Last Accessed 30th July 2018.

Kay, J. J., Regier, H. A., Boyle, M., and Francis, G. (1999). An ecosystem approach for sustainability: addressing the challenge of complexity. Futures, 31(7), 721-742.

Kay, J. J., and Schneider, E. (1994). Embracing complexity: the challenge of the ecosystem approach. Alternatives Journal, 20(3), 32-39

Koestler, A. (1969) Beyond atomism and holism: The concept of the holon. In A. Koestler and J.R. Smythes (Eds) Beyond Reductionism: New Perspectives in the Life Sciences, pp. 192-232. Hutchinson, London.

Kowzan, P., Zielińska, M., and Prusinowska, M. (2014). Intervention in lectures as a form of social movement pedagogy and a pedagogical method. Interface: a journal for and about social movements, 6, 297-326.

Krueger, R.A. (1988) Focus Groups: A Practical Guide for Applied Research. $1^{\text {st }}$ Ed. London, Sage.

Lamond, I.R. (2018) Conceptualising events of dissent: Understanding the Lava Jato rally in Sao Paulo - 5th December 2016. In R. Finkel; B Sharp; M. Sweeny (Eds) Accessibility, Inclusion, and Diversity in Critical Event Studies. Routledge, Basingstoke. 
Markwell, K., and Waitt, G. (2009). Festivals, space and sexuality: Gay pride in Australia. Tourism Geographies, 11(2), 143-168.

Monaghan, J.; Walby, K. (2018) 'Hobocops': Undercover policing's deceptive encounters. Criminological Encounters. 1(1), 7-18.

Mostafanezhad, M. (2018) The geopolitical turn in tourism geographies. Tourism Geographies, 20(2), 343-346.

Mowatt, R. (Forthcoming) Events of dissent, Events of the self. [Book chapter: Full reference not listed in this version as it is in a book the author(s) currently editing; it may therefore infringe the anonymity of this paper's author(s).]

Nind, M. (2011). Participatory data analysis: a step too far? Qualitative Research, 11(4), 349363.

Ooi, C. S. (2019). Indigenisation of scholarship: go native but don't be naive. Conference paper presented at CAUTHE 2019: Sustainability of Tourism, Hospitality and Events in a Disruptive Digital Age. Central Queensland University, Australia. Online at: http://ecite.utas.edu.au Accessed 28 ${ }^{\text {th }}$ May 2019.

Pavoni, A. (2018) Controlling Urban Events: Law, Ethics and the Material. Abingdon, Routledge.

Penn, A. (2016, July). Artificial life and society: Philosophies and tools for experiencing, interacting with and managing real world complex adaptive systems. In Proceedings of the Artificial Life Conference 2016, pp. 26-27. Cambridge, Massachusetts.

Pezzullo, P. C. (2009). Toxic tourism: Rhetorics of pollution, travel, and environmental justice. Tuscaloosa, University of Alabama Press. 
Presence, S. (2013). The political avant-garde: Oppositional documentary in Britain since 1990. Unpublished PhD thesis, University of the West of England. Online at: <http://eprints.uwe.ac.uk/20924/> Last accessed: 30"th July 2018

Puar, J. K. (2002) Circuits of queer mobility: Tourism, travel, and globalization. GLQ: $A$ Journal of Lesbian and Gay Studies, 8(1), 101-137.

Ranciere, J. (2014) Hatred of Democracy. Verso, London.

Reidsema, C., Kavanagh, L., Hadgraft, R., and Smith, N. (Eds.). (2017). The flipped classroom: Practice and practices in higher education. Springer Nature, Singapore.

Roberts, J. (2005). The power of the 'imaginary' in disciplinary processes. Organization, 12(5), 619-642.

Robertson, M., Ong, F., Lockstone-Binney, L., \& Ali-Knight, J. (2018). Critical event studiesissues and perspectives. Event Management, 22(6), 865-874

Robson, C. and McCartan, K. (2016) Real World Research. $4^{\text {th }}$ Ed. John Wiley \& Sons, Chichester.

Rojek, C. (2013) Event Power: How Global Events Manage and Manipulate. Sage, London.

Sabatier, P. A., and Weible, C. M. (2007). The advocacy coalition framework. Theories of the policy process, 2, 189-220.

Schlembach, R. (2018) Undercover policing and the spectre of 'domestic extremism': The covert surveillance of environmental activism in Britain. Social Movement Studies. 17(5), 491-506.

Smith, D.E. (2007) Making change from below. Socialist Studies. 3(2), 7-30

Spracklen, K. (2011) Constructing Leisure: Historical and Philosophical Debates. Palgrave Macmillan, Basingstoke.

Spracklen, K. and Lamond, I.R. (2016) Critical Event Studies. Routledge, Abingdon. 
Teghtsoonian, K. (2016) Methods, discourse, activism: Comparing institutional ethnography and governmentality. Critical Policy Studies. 10(3), 330-347.

Torre, M. E., Fine, M., Stoudt, B. G., \& Fox, M. (2012). Critical participatory action research as public science.

Tsou, M. H. (2015). Research challenges and opportunities in mapping social media and Big Data. Cartography and Geographic Information Science, 42(sup1), 70-74.

Urry, J. (1990) The Tourist Gaze: Leisure and Travel in Contemporary Societies. Sage, London.

Urry, J. (2001) Globalising the tourist gaze. In S. Babu; S. Mishra; and B.B. Parida (Eds) Tourism Development Revisited: Concepts, Issues and Paradigms, pp. 150-160. Response, Los Angeles.

Walgrave, S. and Rucht, D. (Eds) (2010) The World Says No to War: Demonstrations Against the War on Iraq. University of Minnesota Press, Minneapolis.

Walker, M. (2015). The productive and disruptive methodology of doing fieldwork at work. Area, 47(4), 473-478.

Waltner-Toews, D., \& Kay, J. (2005). The evolution of an ecosystem approach: the diamond schematic and an adaptive methodology for ecosystem sustainability and health. Ecology and Society, 10(1), 38-53.

Zielińska, M., Kowzan, P., and Prusinowska, M. (2011). Social movement learning: From radical imagination to disempowerment? Studies in the Education of Adults, 43(2), 251-267. 


\footnotetext{
' Not all activist partners wish to be identified; however, those that are were: Film Fringe (A Yorkshire based film screening group interested in the role film can play in activism. It is also part of the global Radical Film Network and provided links to that network); Leeds Tidal ( $A$ cross-social movements support group based in Leeds, but supports activist groups across West Yorkshire); Yorkshire MESMAC (A sexual health and sexuality awareness charity supporting the LGBT+ community); though not a formal representative we also had an active member of Yorkshire CND (Campaign for Nuclear Disarmament).

ii An analogous approach, one of participant led photo-elicitation, was adopted by Amsden et al (2010) in their study of the sense of place held by tourism-dependent communities.

iii Rescued food, sometimes referred to as food salvage, is the use of edible food that would otherwise be thrown away from traditional food outlets (such as supermarkets and restaurants). See, for example, the work of https://therealjunkfoodproject.org/ and https://feedbackglobal.org/

iv The Commoners Choir is a West Yorkshire based people's choir. Mainly perform their own music, their work has been presented around the UK and Europe. They have their own YouTube channel, which is worth a look.

$\checkmark$ Black and Minority Ethnic

vi Chapter 3 is entitled, Democracy, Republic, Representation; pp. 51-70 in the Verso edition, translated by Steve Corcoran.
} 